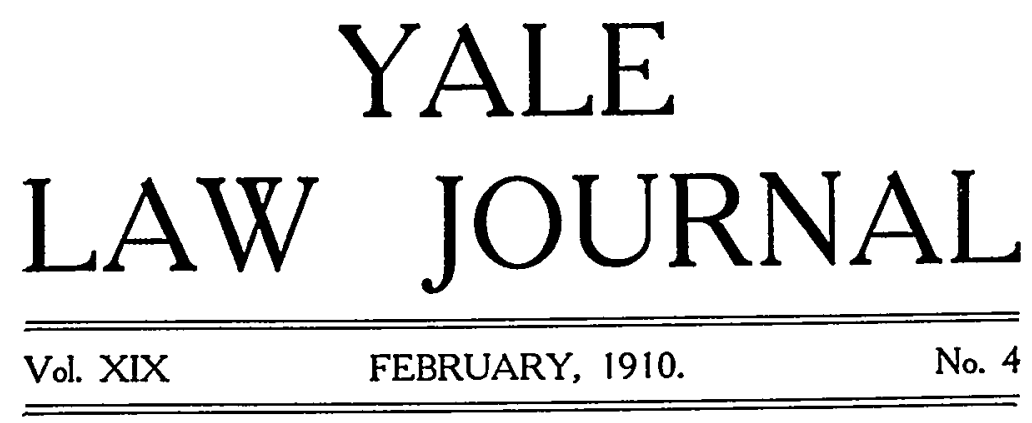

\title{
WAIVER OF TORT AND SUIT IN ASSUMPSIT.
}

This subject has already been developed exhaustively and with great accuracy. ${ }^{1}$ Yet it is a subject in which there has always been great confusion of thought, and the decisions are in hopeless conflict. This is due to the fact that the substantive principles of the common law were developed as mere incidents to forms of action and procedure. The common law system of procedure afforded no remedy in many cases where common notions of justice acknowledged the existence of a right. The system, therefore, had to change, as it ever must continue to change. Before the modes and forms of procedure had crystalized into a system, these changes were easy. The king's courts could make new law by authority of the king. But the kings grew weak and the system of procedure grew stiff. Changes in it grew hard, and many acknowledged rights were without a remedy. New remedies must be invented for these rights, or old remedies must be expanded to include them. The latter alternative was easier because it involved less appearance of innovation. The greatest single step in applying it was the Statute of Westminister II, when Edward $I$ and his law-givers authorized the granting of writs in consimili casu.

This is not the place to explain that statute, or to trace the history of that action curiously called an "action on the case" and its descendants. That is now common knowledge to legal historians. ${ }^{2}$ But it suffices to say that this statute and the applica-

1 Keener: Quasi-Contracts, 159-2I3.

2 Ames: History of Assumpsit and other articles in Essays in AngloAmerican Legal History, Vol. III. Street: Foundations of Legal Liability. 
tion of old remedies to new rights caused lawyers and judges, from that day to this, to describe the new rights in the same terms as the old rights. The habit is inveterate and the results are often pernicious. The new rights are actually different from the old rights, but it requires a clear head for analysis and some knowledge of legal history to tell them apart and to understand their true character. A great many of those rights now usually referred to as quasi-contractual are among these newly recognized rights. But they have long been described in the terms applicable to real contracts and enforced as if they were really contractual. An examination of the cases dealing with them will quickly demonstrate how many are the judges who do not understand their true character, and how easy it is to be led astray by the misleading terminology .

The term "contract," defining it according to the substance and not according to its history, ${ }^{3}$ applies to one large class of transactions. The great distinctive feature of these transactions is the agreement of the parties, the mutual assent, the meeting of the minds. This agreement is the origin of the obligation attached by the law and called contractual. The obligation not to commit a crime or a tort, or to repair the damage caused by a crime or a tort, is not contractual. Further, the character of the obligation is determined by the existence of agreement and not by the kind of eridence by which the existence of agreement is proved to a court. This evidence is of two general kinds, the evidence of words used by the parties, and the evidence of acts other than words. It is somewhat misleading to refer to these two kinds of evidence as direct and circumstantial, for in fact words are just as circumstantial in their character as other acts are. There is no such thing as direct evidence of agreement. Intention is a purely mental phenomenon. If it could be laid bare by a psycho-surgical operation, the one who saw or felt it could give what the law calls direct evidence. No one else can. Contracts, however, are often classified in accordance with the kind of evidence given to establish them. If it is the evidence of words, they

3 We should not here define "contract" according to the historical uses of that term, or according to the forms of action called contractual, for it is here our object to get at the substance and nature of things and not at their vestments or their history. For this reason a work on QuasiContracts should include judgments, statutory duties, and the like, even though, as one author contends, they were real debts, and all debts were historically called contracts. 
are called express contracts. If it is the evidence of acts, they are called implied contracts. But as shown above, both are inferences from the facts proved.

It is important to note that either kind of evidence may lead to a false conclusion. The court may decide that there was an agreement when in fact there was none. It is as difficult to determine the intention with which words were used as it is to determine the intention with which acts were done. So then, a verbal or express contract, as found by the court, is no more certainly a real contract than is a contract implied from acts. Practically, it is necessary for us to say that any agreement found by the court to exist is a real agreement. In law as in metaphysics, human beings must judge of reality by the evidence and according to their capacity of understanding it. To them the real is that which seems real. The reality that does not appear has no practical existence. It is of no consequence that the contract might not appear real to beings other than human.

Some authors attempt to determine the character of a transaction by the form of action applicable to it at common law. But these forms were not mutually exclusive, and the fact that one may sue in indebitatus assumpst on the common counts does not prove that there was or was not a real contract, or even an express contract. ${ }^{5}$ The distinction between a real contract, express or implied, and a quasi-contract is to be found in the presence or absence of the element of agreement. The forms of action available for their enforcement are the same.

The logical distinctions between contract and quasi-contract seem to fade away into obscurity, when a close study is made of the subject of "conditions implied by the law," or of cases holding a party according to the legal meaning of his words wholly irrespective of the fact that his real intention was otherwise. ${ }^{B}$ A discussion of these cases cannot be attempted here. They seem to be combinations of quasi-contract with real contract; though it is usually said that where there is a real and valid contract covering a situation, the law will not "imply" a contract." They will

\footnotetext{
4 See Street: Foundations of Legal Liability, Vol. II, p. 201.

6. g. See Lewis v. Campbell, 8 M. G. \& S., 54I.

- Mansfield v. Hodgdon, 147 Mass., 304; Ayer v. W. U. Tel. Co., 79 Me., 493.

7 Toussaint v. Martinnant, 2 T. R., 100; Roosevelt v. Mark, 6 Johns. Ch., 266. Compare Lewis v. Campbell, 8 M. G. \& S., 54I.
} 
often do so, however, in cases where the express contract was unenforceable or voidable.

The least thought given to the matter will convince one that where one is allowed to waive a tort and to sue in assumpsit, the obligation of the defendant is not really contractual. It is not based on agreement or consent. The chief thing it has in common with a promissory obligation is that it can be enforced by an action in that stereotyped form called assumpsit. ${ }^{8}$ But sometimes not even the least thought has been given, and the result is unreasonable conflict, bad logic, and bad law. The following is offered as an outline of the cases where a tort has been supposed to give rise to a quasi-contractual obligation, as well as the delictual one. A full discussion of all the topics cannot be given here.

I. Basic Principle.
A. An Unjust Enrichment.
B. Theory of Ratification.

II. Torts Affecting Personal Property.

A. Chattels Converted.

I. Money.

2. Goods.
a. Sold for money.
b. Traded for land or goods.
c. Consumed or kept.
d. Used and returned.

\section{B. Property Obtained by Fraud or Duress. \\ C. Infringement of Incorporeal Rights.}

\footnotetext{
8 In assumpsit to enforce this obligation, infancy of the defendant is not a good defense. Bristow v. Eastman, I Esp., r72; Catts v. Phalen, 2 How., 376. Nor is insanity. See Sceva v. True, 53 N. H., 627. Neither should coverture be a good defense; hence dicta in Nat'l Trust Co. $v$. Gleason, 77 N. Y., 400, indicating that the liability of a married woman in assumpsit must be based upon the liability of her separate estate should be disapproved.
} 
III. Torts Affecting Real Property.

A. Use and Occupation by Trespassers.

B. Chattels Severed by Disseisor.

C. Chattels Converted by a Mere Trespasser.

IV. Torts Affecting the Person; Work and Labor.
A. Self.
B. Minor Child.
C. Apprentice.
D. Servant.
E. Slave. (See also II, A, 2, d.)

V. General Doctrines.

A. Application of Statute of Limitations.

B. Survival of Actions.

C. Set-Off and Counterclaim.

D. Election of Remedies.

I. Against a sole tort feasor.

2. Against joint tort feasors.

3. Against successive tort feasors.

4. Question of title to converted goods.

E. Measure of Recovery.

I. Basic Principle-A. An Unjust Enrichment. Since the common law furnished a variety of actions sounding in tort, it may appear that permission to use assumpsit also is entirely unnecessary. It will be found, indeed, that the courts have permitted the use of assumpsit only in those cases where the facts show a shadow of excuse for asserting that the parties have agreed. It is this shadow of an excuse that has often deceived the courts into believing that there was actually a contract relation, and it is probable that had the courts not been so deceived, the remedy in assumpsit would have been extended far less than it has been. The one excuse that is common to all the 
cases with which we are now dealing will be found to be the existence of a moral obligation arising out of an unjust enrichment. It is not enough that a moral obligation exists, for such an obligation exists in all cases of crimes and torts. If $A$ batters B's face, or breaks B's window, or shoots B's cow, or destroys B's grain, a duty to act certainly devolves upon A immediately. He should repair the damage, and the law will compel him to repair the damage, but B cannot use the action of assumpsit. B can use that action only in case A's wrongful act has resulted in A's unjust enrichment. In such case $A$ has a sum of money or other property in his possession, and he is under a duty of giving it to $B$. This duty has much the appearance of a debt. A is said to owe $\mathrm{B}$ something. It is not unnatural, therefore. that the courts should have permitted $B$ to use that highly flexible and generally beneficial action of assimpsit. It had alieady become a proper action to bring for the collection of a debt," the words of the plaintiff's declaration being indebitatus assumpsit. But there must be something to make it appear that the defendant is indebted. That thing is an unjust enrichment. This enrichment must be of such a sort that the courts can see the applicability of one of the common counts in assumpsit. ${ }^{\text {a a }}$ Obviously, a count upon a special promise cannot be maintained; but the law had learned now to "imply" a promise where there was money had and received by the defendant, or where goods had been sold to him without fixing a price, or where services had been rendered for him without an agreed wage, and in other cases. To maintain any of these common counts, it will be found that the defendant must have received a benefit, and this is as true of quasi-contractual actions where the law is asked to construe a promise, as it is of really contractual actions where the defendant impliedly promised in fact. An action on a special promise may be maintained if the promisee incurred a detriment in return therefor, whether the promisor got a benefit or not; but a debt cannot exist unless the defendant has received something, and so the action of debt and the related action of indebitatus assumpsit cannot be maintained unless the defendant has received a benefit. This is the whole doctrine of consideration.

So it must again be stated, a tort may be waived and a suit in assumpsit maintained only when the tort feasor has been unjustly

'Slade's Cases (1602), 4 Co. Rep., 92a.

9a But see Bachelder v. Fisk, I7 Mass., 464. 
enriched by his tort.10 In no case can the recovery in assumpsit exceed that enrichment. ${ }^{11}$

There are a few cases that are apparently in conflict with this principle. They are not numerous; some of them are capable of a fairly plausible explanation; the others must be regarded as erroneous. ${ }^{12}$ Where the payment of money has been unjustly compelled by one who sends an agent to receive it, the agent has been held personally liable in assumpsit, even though he has turned the money over to his principal in accordance with the latter's instructions. But this should be permitted only where the payment was made to the agent under protest and with notice that the agent himself would be held responsible for the amount. ${ }^{13}$ In such case the injured party perhaps has the right to regard the money as having enriched the agent personally. If the wrongdoer has once been enriched, it is of course, immaterial what he does with the money. He is liable in assumpsit, even though he has given the money away, or has lost it at roulette or on the stock exchange. ${ }^{14}$

Where the defendant's tort enriches him only negatively, by enabling him to save money when he would otherwise have had to spend it, it is perhaps generally held that he is not liable in assumpsit, but only in a tort action. ${ }^{15}$ Probably the rule should be otherwise. ${ }^{18}$

${ }^{10}$ Hambly v. Trott, Cowp., 37I ; Osborn v. Bell, 5 Denio, 370; People v. Gibbs, 9 Wend., 29; Webster v. Drinkwater, 5 Greenlee (Me.), 319; Patterson v. Prior, I8 Ind., 440; Fanson v. Linsley, $20 \mathrm{Kan} ., 235$; Downs v. Finnegan, 58 Minn., II2; Reynolds v. Padgett, 94 Ga., 347. Keener: Quasi-Contracts, 160.

${ }^{11}$ Huganir v. Cotter, 102 Wis., 323. And see infra, V, E.

${ }^{12}$ e. g. Eades v. Vandeput, 5 East, 39a, 39.

13 Young v. Marshall, 8 Bing., 43; Osborn v. Bell, 5 Denio, 370; Elliott v. Swartwout, ro Pet., 137. The case of Hindmarch v. Hoffman, 127 $\mathrm{Pa}$., 284, can perhaps be explained on this ground; but if not, it must be disapproved. The rule there adopted certainly puts a bank or other depositary in a, very unfortunate position.

14 For similar reasons a principal may be held liable in assumpsit, even though his agent to perpetrate the wrong received the money and absconded with it. Nat'l Trust Co. v. Gleason, 77 N. Y., 400.

15 Phillips v. Homfray, L. R. 24 Ch. D., 439.

${ }^{16}$ Sollers v. Lazerence, Willes, 413; Keener: Quasi-Contracts, I63-165; note in Scott's Cases on $Q . C ., 99$. The dissenting opinion of Bagallay, L. J., in Phillips v. Homfray, supra, is strongly persuasive. Compare also cases of assumpsit by a surety to compel contribution by a co-surety, or by one whose goods have been jettisoned to enforce the doctrine of general average. 
B. Theory of Ratification. Another theory upon which the action of assumpsit has been sustained is that the plaintiff may ratify the defendant's act, and thus make right that which before was wrong. ${ }^{17}$ But this is only another effort on the part of the courts to find a real contractual relation. It is mere shadow with no substance. The doctrine of ratification properly applies only to cases of real contracts made voidable at the option of one party thereto by fraud, infancy, or the like. In the law of agency it applies only where one has contracted on behalf of another and in that other's name. In all such cases the purpose of the ratification is the recognition of an express contract. In some of these cases the ratification amounts to a waiver of a tort, but it also amounts to an election to stand upon an express contract. ${ }^{18}$ In many of these cases there is no tort to waive; in all of them it is an express contract that is ratified, and not a tort. The doctrine of ratification is inapplicable in cases of indebitatus assumpsit used as a remedy for a tort wholly independent of a contract. ${ }^{19}$

II. Torts Affecting Personal Property-A. Chattels Converted.-I. Money. Where money has been tortiously taken, the wrongdoer may be sued in assumpsit, the count being for money had and received. ${ }^{20}$ Of course an action cannot be maintained against an innocent holder for value, to whom the money has been paid by the wrongdoer. ${ }^{21}$

2. Goods-a. Where goods have been tortiously taken, the wrongdoer may be held in a count for money had and received, in case he has converted the goods into money. ${ }^{22}$ If the conver-

${ }^{17}$ See Terry v. Munger, I21 N. Y., I6r, and cf. Tottenham \& Bedingfield's case (I573), 2 Leon., 24. But see below, V, A and V, D, 2 and 3 .

18 Campbell v. Fleming, I Adol. \& El., 40; Marsh v. Keating, I Montagu \& Ayrton (H. of L.), 582. In Vaughan v. Matthezs, I3 Q. B., I87, the doctrine of ratification is properly held not to apply although in that case a quasi-contract should perhaps have been recognized on other grounds.

${ }^{19}$ Huffman v. Hughlett, II Lea (Tenn.), 549; Rice v. Reed (I900), I Q. B., 54; Bosanquet, J., in Yourg v. Marshall, 8 Bing., 43; Keener: Quasi-Contracts, I67.

${ }^{20}$ Clark v. Shee, Cowp., 197; Neate v. Harding, 6 Exch., 349; Catts v. Phalen, 2 How., 376; Lockwood v. Kelsea, 41 N. H., I85; Hindmarch v. Hoffman, I27 Pa., 284; Brown v. Browen, 40 Hun., 418; Western Assur. Co. v. Towle, 65 Wis., 247; State Nat'l Bank v. Payne, 56 Ill. App., I47.

21 Stephents v. Board of Ed., 79 N. Y., 183; Bank of Charleston v. Bank of State, I3 Rich. L. (S. C.), 291.

${ }^{22}$ Lamine v. Dorrell, 2 Ld. Raym., I216. 
ter of the goods was the defendant's agent, the defendant is liable in assumpsit, even though he is innocent. ${ }^{23}$ The right to sue in assumpsit is generally regarded as accruing at the time the wrongdoer receives the money. ${ }^{24}$

b. Where the wrongdoer has traded the goods for other property, he may be held liable in assumpsit in case the other property has been taken at an agreed price, the seller having the right to receive money, but commuting it into goods. ${ }^{25}$ It is then regarded that the wrongdoer has received money and invested it. This is a mere subterfuge, however, to support a count for money had and received. The count really applicable is one for goods sold and delivered.

c. Where the wrongdoer has not transferred the goods at all, but has consumed or kept them, many courts hold that he may be sued in assumpsit as for goods sold to him. ${ }^{28}$ Perhaps the weight of authority is contra. ${ }^{27}$ The cases contra should be disapproved. There is really no magic in the receipt of money, out of which to construct a contractual relation. The wrongdoer is a tort feasor, not a contractor, whether he sells the converted goods or keeps them. He is under the same sort of a duty in either case, and it is no more difficult for the law to enforce that duty in a count for goods sold than in a count for money had and received.

d. Where the goods taken have been used and returned, it has wrongfully deprived the plaintiff, may be recovered in inassumpsit. ${ }^{28}$ The fiction of a hiring is then indulged.

In all of the cases of conversion, the recovery in assumpsit must be limited to the amount of the wrongdoer's enrichment.

${ }^{28}$ Marsh v. Keating, I Montagu \& Ayrton, 582.

24 But see infra, V. A.

${ }^{25}$ Miller v. Miller, 7 Pick., I33, and see Kidney 'v. Persons, 4I Vt., 386.

${ }^{26}$ Hill v. Perrott, 3 Taunton, 274; Roth v. Palmer, 27 Barb., 652; Kirkman v. Philips, 7 Heisk., 222; Phelps v. Church, 99 Fed., 683; Crozun Cycle Co. v. Brown, 39 Ore., 285; Ferrill v. Mooney, 33 Tex., 219; Roberts v. Evans, 43 Cal., 380; Downs v. Finnegan, 58 Minn., I12; Braithuaite v. Akin, 3 N. D., 365. Keener: Quasi-Contracts, 193.

${ }^{27}$ Watson v. Stever, 25 Mich., 386; Whipple v. Stephens, 25 R. I., 563; Kidney v. Persons, 4I Vt., 386; Bowman v. Browning, I7 Ark., 599, and Keener: Q.-C., supra.

${ }^{28}$ Fanson v. Linsley, 20 Kan., 235; Hambly v. Trott, Cowper, 37J (dictum), and see below, IV. 
B. Property Obtained by Frand or Duress. The rules laid down in relation to goods converted properly apply here $;^{29}$ but there are some special questions to be answered. When credit is obtained tortiously, the agreement may of course be avoided and the wrongdoer held at once in a tort action. It would seem that the injured party would then, as in the case of any other tort resulting in enrichment, have the choice of suing in a tort action or of suing in assumpsit. It has been properly held that he has such a choice. ${ }^{30}$ The cases contra ${ }^{31}$ rest upon the incorrect idea that suing in assumpsit is an affirmation of the contract. It is, of course, true, that a voidable contract cannot be affirmed in part and avoided in part. So here the defrauded party cannot sue for the contract price before the term of credit has expired. A suit for the contract price is a suit in express assumpsit on the express contract; but a suit against a tort feasor for the amount of his enrichment is in indebitatus assumpsit, and pre-supposes no contract whatever. The courts have often erroneously supposed that it does pre-suppose a real contract relation.

On the subject of duress also, there has been some confusion of thought. This is not the place to discuss the whole matter. The term has been used to denote violence or imprisonment, actual or threatened, sufficient to render voidable a contract otherwise valid. Where such violence or imprisonment amounts to a tort, it is doubtful whether a suit in assumpsit to recover money obtained by the duress, would amount to a waiver of the tort at all. It could not be such a waiver where the violence was toward a third person, some near relative of the person whose will was overpowered. An action of assumpsit by the latter would be quite consistent with a contemporaneous action of trespass by the third person. Further, it does not appear that they would be inconsistent if maintained at the same time by the same person. If A batters $B$ and thereby causes $B$ to give up property, perhaps B could maintain both trespass and trover. If so, he can maintain

${ }^{20}$ e. g. Abbotts v. Barry, 2 Brod, \& Bing., 369.

${ }^{30}$ Roth v. Palmer, 27 Barb., 652; Crown Cycle Co. v. Brown, 39 Ore., 285; Dietz v. Sutcliffe, $80 \mathrm{Ky} ., 650$; Keener: Q.-C., Ig6-I99.

${ }^{31}$ Kellogg v. Turpie, 93 Ill., 265; Ferguson v. Carrington, 9 B. \& C., 59, and Selway v. Fogg, 5 M. \& W., 83, are both to the same effect, but in both cases there was really no disaffirmance of the fraud and the plaintiff was keeping benefits under the contract, so that he could not have sued in tort either. Of course the existence of a right to sue in tort is a prerequisite to a suit in indebitatus assumpsit in these cases. 
both trespass and assumpsit, though he could not maintain both trover and assumpsit.

The term duress has also been used to denote such an amount of improper influence, other than violence or imprisonment, as will prevent a payment from being voluntary. In this sense it is not sufficient to set aside an otherwise valid contract; but it is sufficient to enable one making a payment to recover in assumpsit, in cases where there was no consideration given for the money paid, or where for any other reason there was no contract at all. Title to the money did not pass by contract, for there was none; and the duress shows that there was no voluntary gift. It is in this sense only that there is such a thing as duress of goods. In some cases of this sort there is no tort to be waived; but in all such cases, whether the duress amounts to a tort or not, the one paying the money may recover it in assumpsit. If instead of money, one has been influenced to deliver other property, he may substitute assumpsit for a tort action in accordance with the principles set out above under II, A.

C. Infringement of Incorporeal Rights. Where one tortiously infringes another's incorporeal rights, as for example a patent right, and has made a profit thereby, such profit is an unjust enrichment, and it has been held that assumpsit will lie. ${ }^{82}$ The remedy may often preferably be by bill in equity for an accounting, because of the complicated nature of the account, but in simpler cases assumpsit for money had and received should lie. There is ample authority for the use of assumpsit, this form having in fact supplanted the former common law action of account. ${ }^{\mathrm{sB}}$ So also, the profits of an office of which the defendant has wrongfully deprived the plaintiff, may be recovered in indebitatus assumpsit. ${ }^{34}$ In this last case the measure of damages is said to be the salary or fees wrongfully received by the defendant, with no deductions for what the plaintiff may have earned while so ousted. ${ }^{85}$

32 Head v. Porter, 70 Fed., 498; McSorley v. Faulkner, 18 N. Y. Supp., 460 (right to use telephone); Keener: Quasi-Contracts, 165; Cf. Schillinger v. U. S., I55 U. S., I63, and Phillips v. Homfroy, I. R. 24 Ch. D., 439, both of which are distinguishable.

33 See Ames: History of Assumpsit. Asher v. Wallis, II Mod., I46.

84 Arris v. Stukely, 2 Mod., 260; Kreitz v. Behrensmeyer, 149 Ill., 496.

${ }^{80}$ Fitzsimmons v. Brooklyn, I02 N. Y., 536; U. S. v. Addison, 6 Wall., 291. 
III. Torts Affecting Real Property-A. Use and Occupation by Trespassers. As against one who is not a tenant by virtue of a real agreement, express or implied, the value of the use of real property has never been recoverable in the action of assumpsit. ${ }^{36}$ There is no logical reason for this doctrine, for there is the same duty and the same unjust enrichment as in other cases. Certain historical reasons for the refusal to allow assumpsit for use and occupation against a trespasser have been suggested. For example, it is said that "it would have been extraordinary had the courts given a remedy against a tort feasor which they did not allow on a contract against a tenant." 37 But, with deference, it would not have been extraordinary at all. There was a good reason for not extending assumpsit to suits against tenants. Against them the landlord had another perfectly adequate contractual remedy, the action of debt. In debt for rent reserved the tenant could not wage his law and the action survived the tenant's death, so why should the landlord want assumpsit? But against a trespasser the owner has no right of action in debt. The trespasser is unjustly enriched, and the plaintiff has as much need of the remedy in assumpsit as in the case of any other tort enriching the tort feasor. The reason given by Professor Ames for not allowing assumpsit against a trespasser is a better one; the remedy of indebitatus assumpsit was allowed by special act of Parliament against a tenant upon a parol demise, and "the courts could not, without too palpable a usurpation, extend the count to cases not within the act of Parliament." It would have drawn too close a parallel between Parliamentary legislation and judicial legislation. ${ }^{38}$ If the trespasser occupies under a claim of right, thus beconing a disseisor, it is doubtless improper to allow

36 Tew v. Jones, I3 M. \& W., I2; Smith v. Stewart, 6 Johns. (N. Y.), 46; Ackerman v. Lyman, 20 Wis., 454; Hurley v. Lamoreaux, 29 Minn., 138. Yet the court had no difficulty in permitting a woman to maintain assumpsit against a man who had fraudulently induced her into a void marriage with him, and had then received the rents and profits of her real property. Asher v. Wallis, II Mod., 146. And see dictum in Nat'l Oil Ref. Co. v. Bush., 88 Pa., 335. The case of Mayor v. Saunders, 3 B. \& Adol., $4 \mathrm{II}$, where assumpsit was allowed to recover stallage in a public market appears to be contra, but it may be that the defendant was not a trespasser in that case.

37 Keener: Quasi-Contracts, I92.

3s The statute was II Geo., II, c. I9, Sect., 14. See Ames: History of Assumpsit; also Street: Foundations of Legal Liability, Vol. II, p. 2I7. 
the plaintiff to litigate the question of title in an action of assumpsit. ${ }^{\text {s9 }}$

B. Chattels Severed by Disseisor. If a disseisor of land severs trees or stone and converts them to his own use, the disseisee cannot maintain assumpsit. ${ }^{40}$ This is because the trees and stone were not technically the property of the disseisee at the time of severance. The question of right to the trees depends upon the larger question of right to the land, and assumpsit is not a proper action for the trial of that question.

C. In case of trespasses where there is not also a disseisin, there is usually no enrichment, and so no right to sue in assumpsit. But if while trespassing without also disseising, the trespasser commits the further tort of converting property to his own use, it has been held that a suit in assumpsit will lie. ${ }^{41}$ This should amount to a waiver of the conversion, and probably also of the trespass quare clausum. The whole is probably to be regarded as a single cause of action, and the owner could not maintain both trespass and trover.

IV. Torts Affecting the Person; Labor Compelled. Where one has been enriched by tortiously compelling another to work for him, that other should have the right to sue in indebitatus assumpsit. ${ }^{42}$ There exists the combination of duty and enrichment in this case. The count is for work and labor, quantum meruit, instead of for money had and received. The remedy in this case has been refused, however, for mistaken reasons similar to those in actions for good sold.4s

39 See Lindon v. Hooper, Cowper, 414; Phelps v. Church, 99 Fed., 683; Downs v. Finnegan, $58 \mathrm{Minn} .$, I12. In fact there is little need of the remedy in any case; courts have many times shown their disinclination to extend the remedy; perhaps the refusal here is another illustration of their disinclination.

10 Keener: Quasi-Contracts, I72; Ames: Disseisin of Chattels, Essays in Anglo-American Legal History, Vol. III, p. 547 ; Downs v. Finnegan, 58 Minn., II2.

11 Phelps v. Church, 99 Fed., 683 (stone severed) ; Norden v. Jones, 33 Wis., 600 (pasturage of trespassing cattle); Welch v. Bagg, I2 Mich., 42 (pasturage); Powell v. Rees, 7 Adol. \& El.,. 426 (coal severed); Phillips v. Homfray, 24 Ch. D., 439 (coal). Cf. Stearns v. Dillingham, 22 Vt., 624 .

12 Patterson v. Prior, I8 Ind.; 440; Abbott v. Town of Fremont, 34

N. H., 432.

${ }^{43}$ Thompson v. Bronk, I26 Mich., 455. 
If one's minor child or apprentice has been forced or enticed away, and has been induced to serve defendant, thus enriching him, the parent or master may sue in assumpsit for the value of the service rendered. ${ }^{44}$ This rule ought not to apply, however, in the case of an ordinary servant by contract. If the servant once finally breaks the service contract, the master is no longer entitled to his service; and this is true whether the breaking of the contract was due to the defendant's solicitation or not. Hence, even though the service received by the defendant is of greater value to him than the wages paid by him, there is no unjust enrichment, by service to which the plaintiff was entitled. In the case of the child or apprentice, the relation cannot be conclusively ended without the master's consent, and the master therefore remains entitled to the service received by the defendant. The only remedy, therefore, against one who entices away a servant, is in tort.

One who enriches himself by the use of another's slave is liable in assumpsit for like reasons; but this is governed by principles discussed above, in dealing with the conversion of chattels used and returned. ${ }^{45}$

V. General Doctrines-A. Application of the Statute of Limitations. Statutes of limitation very generally fix one period of time as sufficient to bar an action on a contract, and a different period of time to bar an action for a tort. In case a tort is waived and suit brought in assumpsit, which period applies? Of course the intention of the legislature should control, but unfortunately the legislature usually has no intention, and the meaning of the law must be determined by the reasonable construction of the words. The statutory words may mean "after the existence of a cause of action," or they may mean "after the availability of a form of action." If the words have the latter meaning, no difficulty will arise, and the right to sue in assumpsit will be barred after the number of years specifically allowed for actions of assumpsit. However, statutes are not usually so worded as to refer to forms of action; they usually classify cases according to the cause of action. Perhaps no difficulty should arise in construing this sort of a statute either, but difficulties have arisen.

${ }^{44}$ Lightly v. Clouston, I Taunton, II2; Eades v. Vandeput, 5 East, 39a, 39; Foster v. Stewart, 3 Maule \& S., I9I ; Hopf v. U. S. Baking Co., 6 Misc. (N. Y.), I58 (minor child); Keener: Q.-C., I89.

45 Stockett v. Watkins, 2 G. \& J. (Md.), 326; contra, Crow v. Boyd, I7 Ala., 51 . 
Suppose a statute limits actions for damages for a tort to three years after the commission of the tort, and actions on contracts to six years after the accrual of the cause of action. Then if $B$ converts A's chattel in rgoo, sells it to $C$ in Igor, and receives the price from $C$ in I902, how soon is $A$ 's remedy against $B$ barred by the statute? It is clear that A could sue in trespass, trover, or replevin no later than 1903 . But it has been held that $A$ could sue $B$ in a count for goods sold, as late as $1906 ;^{40}$ and in a count for money had and received, as late as Igo8.17 The reason has been given thus: "Since to maintain an action for money had and received in this class of cases, the plaintiff must prove the receipt of money by the defendant as well as a wrongful conversion, his cause of action does not arise until the receipt of the proceeds of the sale; and therefore the Statute of Limitations begins to run only from that time."18 Professor Keener adds a limitation to the above rule to the effect that if B.should keep A's chattel until 1904 and then sell it for money, A could not sue in assumpsit for that money. This limitation has been sustained in one excellent decision. ${ }^{49}$ and this writer has no quarrel with it. But it is submitted that the rule which it limits is wholly incorrect, and that the decisions sustaining the rule are faulty unless they. can be justified by the peculiar wording of the particular statute to be applied. A's right to sue in assumpsit should be barred at the same time as is his right to sue in a tort action..$^{50}$

In all cases where a tort is waived, there is in fact no contract. The cause of action is a tort, and the tort exists as the cause of action and must be proved as the cause of action from first to last. No trick or legerdemain on the part of the plaintiff can change the tort into a contract. Neither can the law do this. The law may allow new forms of action, and may call things by new names, but it cannot turn a theft or other conversion of goods into an innocent agreement to sell and to buy. The assumpsit alleged in these cases is a mere fiction and is not the cause of action. Professor Keener argues convincingly that the

40 Kirkman v. Phillips, G Heisk., 222.

${ }^{47}$ Miller v. Miller, 7 Pick., 133 .

48 Keener: Quasi-Contracts, I75.

${ }^{49}$ Currier v. Studley, 159 Mass., I7.

${ }^{50}$ This is sustained in principle by Hodsden v. Harridge, 2 Saunders, 64, and other cases holding the contractual period not applicable in the case of other sorts of quasi-contracts. See note 54 below. 
fiction should never be used to deny a remedy, overthrowing several cases where it was so used. ${ }^{51}$ In like manner, it is submitted, the fiction should not be used to enlarge a right. The fact that it has been used to dodge the rule that a personal action dies with the person, ${ }^{52}$ or to expand the right of set-off ${ }^{53}$ which the common law technically and inconveniently limited, is no ground for using it to nullify a legislative act based on sound public policy. It has often been held that in other sorts of quasicontracts, the contractual period of limitation does not apply. ${ }^{54}$ Perhaps in those cases the tort limitation could be no more logically applied than the contractual limitation. But in the cases here considered there is a recognized tort, it is the real cause of action, and the tort limitation should control.

The proponents of the rule here controverted admit that if the statutory period for tort actions has gone by before the converter transfers the thing converted, the count for money had and received will never be maintainable. But they assert that if the thing was transferred the day before the tort remedy was barred, a new cause of action in assumpsit now arises on receipt of the proceeds, and will not be barred until the end of the full period allowed for actions on contracts. "If the title to the property is in the injured party at the time of the sale (by the converter), it would seem that the running of the statute subsequent thereto, but prior to the receipt of the money by the defendant, should not affect the plaintiff's right. $\mathrm{He}$ is equitably entitled to the debt as the proceeds of his property." It is submitted that this is incorrect, and that it makes no difference when the sale was made or when the proceeds were received. The author quoted above has himself shown over and over again that there is in fact no new cause of action and never any real contract. Further than that, it has been convincingly shown that after a conversion

51 Keener: $Q .-C$.; 210-213; see also pp. 159-160.

${ }^{5}$ See below, V, B.

63 See below, V, C.

54 In Hodsden $v$. Harridge ( 1670 ), 2 Saunders, 64 , it was held that the Statute of 21 Jac. I, c. 16, limiting "all actions of debt grounded upon any lending or contract without specialty" to six years, did not apply in an action of debt upon an award. To the same effect, as to other quasicontracts, construing the same or a similar statute, are: Talory v. Jackson (1633), 3 Croke, 513; Jones v. Pope, I Williams' Saunders, 37; Wilson v. Towle, ig N. H., 244; Pease v. Howard, I4 Johns., 479; Richards v. Bickley, 13 Serg. \& R., 395. 
the injured party is at once divested of his title.5 The act of conversion operates to change the title, to chattels as to land. The disseisin changes the ownership into a mere right to obtain possession. The disseisin and not the statute of limitations passes title. The statute merely determines the life of the disseisee's right of action. Further acts of ownership on the part of the disseisor certainly ought not to assist the disseisee and to enlarge his right. When the disseisor sells the thing, he is selling a thing to which he has title, and as to which the disseisee has merely a right of action. After the sale, as before, the disseisee has his right for the remainder of its statutory life. During that period this right can be made the basis of a quasi-contractual action of assumpsit, as well as of a tort action. But when the right expires it cannut be made the basis of anything. There is then no basis left for assumpsit.

But it may be said that, whether technically so or not, justly and equitably the thing is the property of the disseisee, and that therefore the proceeds are his. The answer is that this proves too much. This contention would be just as applicable the day after the full period of the statute has elapsed as it was the day before. As between the parties, the thing still justly belongs to the disseisee; but he cannot get it, nor can he get the proceeds of the thing if it is later sold, however justly he may regard them as his. This is admitted by all. The equity of his case does not in the least depend upon when the tort feasor sold the chattel or received the proceeds; hence, it is evident that the injured party's right to the thing or its proceeds must be determined upon some other principle than so-called "natural justice."

If the plaintiff should be limited to the three year period on his count for money had and received, he should be likewise limited when he sues in a count for the value of goods sold and delivered. In a case holding the contrary, the following paradoxical statements were made: "The statute of limitation applicable to the cause depends upon the nature and character of the action and not upon its form. In the case before us the complainant has elected to waive the tort and to sue for the value of the : property converted, and in so doing he is entitled to the benefit of the six years statute." ${ }^{56}$ It is strange that the court

5s Ames: Disscisin of Chattels, Essays in Anglo-American Legal History, Vol. III, p. 54x.

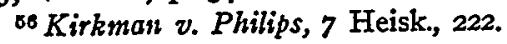


did not see that in the second sentence it was denying the accuracy of the first. It erroneously supposed that there was a new cause of action, really contractual-that the plaintiff could transform water into wine.

B. Survival of Actions. At common law the right of action for a tort does not survive the death of either the plaintiff or the defendant. Actio personalis moritur cum persona. This rule applies to all cases where the tort feasor has caused a damage to another without himself receiving any property or profit; and also to cases where the form of action brought is a tort form and the plea is not guilty, even though there was an enrichment of the tort feasor. ${ }^{8 z}$ So the various forms of trespass will not survive, nor will trover. ${ }^{58}$ But actions sounding in contract or quasicontract do survive. ${ }^{89}$ So in all cases where the injured party may waive the tort and sue in assumpsit, his tort remedy will not survive, but his remedy in assumpsit will survive. ${ }^{60}$ Of course, this rule is judicial legislation to get rid of the unjust doctrine of non-survival of actions, in those cases where its injustice is most apparent. But the whole rule of non-survival of actions was itself judicial legislation, and there is no reason why it should not be repealed by its own creator. Of course, if the tort feasor has not been enriched, he is not liable in assumpsit; and neither is his personal representative liable, even in equity. ${ }^{\text {B1 }}$

C. Set-Off and Counterclaim. Difficulties have arisen in construing statutes allowing set-offs, counterclaims, and recoupment. Of course it is chiefly a matter of statutory construction; but it is well to know what a quasi-contract is, before so construing a statute allowing contractual set-offs as to permit a defendant sued on a promissory note to put in a claim for the value of

${ }^{57}$ Hambly v. Trott, Cowper, 37x. The latter part of this rule of course does not apply in equity; Phillips v. Homfray, 24 Ch. D., 439, Bagallay, L. J.; nor does it apply in jurisdictions where the forms of action are abolished.

${ }^{88}$ Id. Of course a personal representative is liable in tort for a tort committed by him after the death of the decedent. Bishop v. Knight, I P. Williams, 406 .

59 Sollers v. Lawrence, Willes, $4 \mathrm{r} 3$ (customary duty); Perkinson v. Gilford, Croke Car, 539 (official duty).

${ }^{60}$ Bishop v. Knight, I P. Williams, 406 (property converted and sold) ; Head v. Porter, 70 Fed., 498 (profits made by infringing patent); Ferrill v. Mooney, 33 Tex., 219 (cattle killed and used).

o1 Osborn v. Bell, 5 Denio, 370; People v. Gibbs, 9 Wend., 29; Phillips v. Homfray, 24 Ch. D., 439. 
goods converted by the plaintiff. It is sometimes held that such statutes permit quasi-contractual set-offs and counterclaims, even in cases where the quasi-contract is based upon a tort. ${ }^{.2}$ Liberality in construing these statutes is generally desirable, for it avoids multiplicity of actions and promotes justice, so there seems to be no serious objection to allowing a defendant who is sued in a contract action to waive a tort by the plaintiff and to counterclaim against him in assumpsit. But it should be done with a clear understanding that the counterclaim is not contractual and with a decent amount of respect for the actual meaning of the words used by the legislature. ${ }^{63}$

D. Election of Remedies-I. Against a Sole Tort Feasor. An investigation may show that there is much incorrect theory on the subject of election of remedies. It would seem that an election by the party having a choice should not be conclusive upon him, until he has done an act making it impossible for him to choose again, or making it injurious to the public, or unjust to the opposite party. That which is an election as against one party is not necessarily so as against another. The doctrine of election is really an application of the doctrine of estoppel. In those cases where an injured party may waive a tort and sue in assumpsit, he has an election of remedies. But merely bringing suit in one form should not be regarded as a conclusive election.".4 If the plaintiff becomes non-suit or voluntarily dismisses his case, he may again bring the same action; and if so, there is no reason why he should not be allowed to try the alternative form of

62 Gordon v. Bruner, 49 Mo., 570; City Nat'l Bank v. Nat'l Park Bank, 32 Hun., 105; Downs v. Finnegan, 58 Minn., I12.

63 Similar questions arise under other statutes and have been variously decided, but they will not be considered here. Ex parte Adamson, L. R. 8 Ch. D., 807 (statute of bankruptcy) ; Milford v. Com., I44 Mass., 64 (statute allowing suits against the State); People, ex rel. Dusenbury $v$. Speir, 77 N. Y., I44 (statute authorizing arrest in civil cases); Schillinger v. U. S., I55 U. S., I63, and Ingram v. U. S., $32 \mathrm{Ct}$. of Clms., 147 (statute conferring jurisdiction on the court of claims); First Nat'l Bank v. Van Vooris, $6 \mathrm{~S}$. D., 548 (statute permitting attachment of goods).

of The cases are not harmonious. See note in Scott's Cases on Q.-C., p. I48; Keener: Q.-C., 203; article in I6 Law Quar. Rev., I60. Perhaps the bringing of a suit in express assumpsit upon a contract voidable for fraud or infancy, or upon a contract made by an unauthorized agent, should be regarded as a conclusive election; but even if so, it does not follow that the bringing of indebitatus assumpsit upon a quasi-contract founded in tort should be so regarded. 
action the second time. ${ }^{85}$ The first case may even go so far as a judgment adverse to the plaintiff without barring his remedy in another action, but the judgment must not be as to the merits of his cause of action. ${ }^{\text {B }}$ So, where one has been sued in express assumpsit, and sets up infancy as a defense and obtains judgment thereon, he may still be sued in a tort action based on the same transaction. ${ }^{67}$ And if the infant's tort be one resulting in his enrichment, it would seem that he ought to be liable in indebitatus assumpsit also. ${ }^{68}$

After one fair and square judgment on the merits, however, the plaintiff has no right of action remaining in any form. He has had his day in court. If he elects to sue in tort, and judgment goes against him, he is estopped from suing a second time in assumpsit. ${ }^{69}$ Nemo debet bis vexari pro eadem causa. If the plaintiff gets judgment in his favor in the first action, his whole cause of action is merged in the judgment, and the same maxim applies. There is in this case the additional reason that a second judgment in another form of action would generally be of little additional service to the plaintiff. These rules should apply whether the judgment in the plaintiff's favor has been satisfied or not.

2. Against Joint Tort Feasors. Various problems arise under this head, but they are not peculiar to quasi-contracts. In America, joint tort feasors are severally as well as jointly liable, and separate judgments in either tort or assumpsit may be obtained against them. A judgment in assumpsit against one should not bar a subsequent action against the other, the theory that bringing indebitatus assumpsit turns a conversion into a sale being mere fiction. ${ }^{70}$ The limitation is merely that there shall not

65 Whipple v. Stcvens, 25 R. I., 563.

${ }^{88}$ Wilbur v. Gilmore, 21 Pick., 250.

67 Badger v. Phinney, I5 Mass., 359; Walker v. Davis, I Gray, 509.

68 See above, II, B.

"O Hitchin (or Kitchen) v. Campbell, 2 W. B1., 827; 3 Wils., 304; Ware v. Percival, 6r Me., 39r. But as against one who has committed a series of trespasses, a judgment in a tort action for one of them will not har an assumpsit for the others. Powell v. Rees, 7 Adol. \& El., 426.

${ }^{70}$ Contra: Buckland v. Johnson, I5 C. B., I45; Floyd v. Browne, I Rawle, I2r; Terry v. Munger, I2I N. Y., I6I. See Keener: Q.-C., pp. 208-212; convincingly overthrowing these contrary decisions. The fiction of a contract "having been adopted for the purpose of giving a remedy, under a system in which forms were paramount to substance, it should not be used for the purpose of denying a remedy." Also see above, $\mathrm{I}, \mathrm{B}$. 
be double satisfaction. But will a judgment adverse to the plaintiff in his action against one of the joint wrongdoers, bar any further action against another? It is merely suggested here that there are two reasons why it should. First, the plaintiff has had one day in court on the issue of whether there was a joint tort or not. Secondly, it would be unfair to the defendant who won, to be subjected to a further action for contribution by the second defendant who lost, in those cases where contribution would be allowed. ${ }^{\text {70a }}$ Perhaps it can be shown that these reasons should not control. In the case of a joint contract, a judgment in favor of one of the joint promisors was held to bar a later action against the other (in a state allowing by statute a severance of actions) ${ }^{71}$ Even if the contract had been joint and several, perhaps the reasons above given would apply, and would have barred the second action.

3. Against Successive Tort Feasors. Where A's property is converted by $\mathrm{B}$, and it later comes into the hands of $\mathrm{X}$, who also converts it to his own use, A may hold either or both liable, though he is not entitled to double satisfaction. Here a judgment in favor of A, in either tort or assumpsit, against either tort feasor, should not bar an action against the other. It amounts to an election, so far as the one sued is concerned, and that one cannot be sued again in any form. But it is no election as against one not a party to that suit. As to the latter, it is no estoppel, and election and estoppel are the same thing. ${ }^{72}$

Perhaps there is a distinction in case A loses his first suit, this first suit being against the original converter of the property. If $A$ sues $B$, and $B$ gets judgment, this should bar any further suit against $X .^{73}$ The tortious character of X's act depends upon the

30a e. g. As in Bailey v. Bussing, 28 Conn., 455; Palmer v. Wick, etc. Co., L. R. I894, App. Cases, 3I8

71 Cowley v. Patch, I20 Mass., I37.

72 It has been held that where A sued B for money had and received, obtained a temporary injunction to prevent $B$ from disposing of that money, and then settled the case by receiving $f T, 000$ from $B$ but reserving all rights against $\mathrm{X}$, that $\mathrm{A}$ might still sue $\mathrm{X}$ in a tort action. Rice $v$. Reed (1900), I Q. B., 54. This decision is correct. An article in I6 Law Quar. Rev., I60, criticising it, fails to draw the distinction drawn above between sole tort feasors and joint tort feasors and also makes the erroneous assumption that by the plaintiff's action he ratified the tort and turned it into a sale.

${ }^{73}$ Marsh v. Pier, 4 Rawle, 273.' 
character of B's act, and the character of B's act has been forever settled. If $A$ were allowed to hold $X$ in the later action, and $X$ could then hold $B$ for indemnity, this would enable $A$ to hold $B$ indirectly after having once failed to do so directly, a result unjust to $B$. [This is really the only good reason why the discharge of a principal debtor by the creditor should also discharge the surety.] If $\mathrm{X}$ were in such state that he would have no right of indemnity against $B$, the judgment in favor of $B$ should not bar a suit against $X$. But as it could not be determined in the suit between $A$ and $X$ whether or not $X$ will be entitled to indemnity from $B$, probably the only way to avoid the double vexation of $\mathrm{B}$, is to hold that $\mathrm{X}$ is no longer liable to suit. The mere bringing of assumpsit against $\mathrm{B}$, however, not followed to judgment, does not bar a later suit against $X .{ }^{74}$ If, on the other hand, $A$ sues $X$ first and $X$ gets judgment, this should not bar A's remedy against $B$. The character of B's act does not depend upon the character of the act of $\mathrm{X}$. And there is no possibility of the double vexation of $\mathrm{X}$.

In all the above cases, it is quite immaterial what is the form of the actions, whether in assumpsit or in tort. Of course, if B pretended to act as A's agent, then the ratification theory properly applies, and anything that will amount to a ratification of B's unauthorized act, will bar an action against X.7s

4. Question of Title to Converted Goods. In the case of conversion of chattels, the doctrine of election of remedies is mingled with the question of the passing of title. It has been said that a judgment in trespass, trover, or assumpsit against a converter of goods has the effect of passing title to those goods, and that therefore a subsequent converter would become nunc pro tunc an innocent purchaser from the real owner, and so not be liable in a subsequent action. ${ }^{78}$ It is submitted that this is incorrect. The judgment does not pass title at all. In so far as title is passed, it is passed by the original act of conversion or disseisin. ${ }^{77}$ After the disseisin, the injured party's ownership has become a right of action, good as against any holder of the

${ }^{44}$ Huffman v. Hughlett, II Lea, 549; Rice v. Reed (1900), I Q. B., 54.

${ }^{75}$ Marsh v. Pier, 4 Rawle, 273.

${ }^{70}$ Buckland v. Johnson, 15 C. B., 145; Terry v. Munger, I2I N. Y., 16I; dictum in Marsh v. Pier, 4 Rawle, 273, citing authorities.

${ }^{77}$ See Ames: Disseisin of Chattels, III Essays in Anglo-American Legal History, 567-580. 
article, for the period allowed by the statute of limitations. When this period has gone by, the title of the disseisor, or his grantee, formerly limited by an outstanding right of action, now becomes unlimited. So, if the injured party sues the converter in trespass, trover, or assumpsit, and judgment is rendered either for or against him, he cannot thereafter maintain another action against that defendant for the same cause. But such a judgment has nothing to do with the passing of title. It is merely a merger or an estoppel as to the cause of action against that one defendant. If there is no subsequent tort feasor to be sued, then the plaintiff's right of action is wholly gone, and the defendant's title is unlimited. If the judgment is in favor of that defendant. it should estop the plaintiff from again suing any subsequent grantee, as set forth above; and so the disseisor's previous limited title becomes now practically unlimited because of the estoppel. But if the judgment is against that defendant, thus establishing that there was a tort (and this would be established whether the judgment was in tort or in indebitatus assumpsit), and there is a subsequent grantee, there is now no ground for estoppel and there is no merger of the independent cause of action against the latter tort feasor. There is no excuse for saying that title has passed; and the subsequent tort feasor should be suable during the remainder of the period fixed by the statute of limitations, counting from the original conversion. ${ }^{78}$ Of course, both judgments cannot be collected, and if the subsequent tort feasor is compelled to pay, he ought in general to be subrogated to the rights of the plaintiff in the judgment against the first tort feasor.

The theory that bringing suit in assumpsit against the first wrongdoer is a waiver of his tort and a ratification of his act so as to protect subsequent grantees is well enough in case the first wrongdoer professed to act on behalf of the injured party, and made a contract in his name, but in no other cases. ${ }^{79}$

E. Measure of Recovery. Is the action of indebitatus assumpsit in these cases an action for damages for a tort? Yes, it is. Except, because of the form of action used, the damage is to be measured by the value of the goods or use or labor. Other elements of damage are waived. This is what waiving the tort and suing in assumpsit really means. It means suing for a partial reparation for the tort. The waiver is really a waiver of a

78 See Ames: Disseisin of Chattels, supra.

${ }^{79}$ Marsh v. Pier, 4 Rawle, 273, and see above, I, B. 
part of the damage. Often this waiver amounts to very little, because the damage done by the tort is co-extensive with the value of the chattel or the labor by which the defendant is enriched. The amount one gains is the amount of the other's loss. On the other hand, the waiver is often a substantial one. The defendant's gain may be less than the plaintiff's loss.

The amount recoverable in assumpsit can never exceed the defendant's enrichment; ${ }^{80}$ and further, it ought never to be allowed to exceed the amount of the plaintiff's injury. The courts have always based the quasi-contractual action upon the reason that it could not injure the defendant, but instead would in many cases be to his advantage. ${ }^{81}$ In rare cases the amount recoverable has perhaps been allowed to exceed the injury. But this is probably due to the fact that the court supposed that the quasi-contract was a different cause of action. ${ }^{82}$ They have seen clearly enough that the cause of action is the same, in cases turning on the question of remedies and the doctrine of res judicata. They at once apply the maxim nemo debet bis vexari PRO EADEM CAUSA. ${ }^{88}$

But it may be said that the plaintiff ought to recover the full amount of the defendant's unholy enrichment because it is unjust for the defendant to retain any of it. It does not seem so certain, on examination, that this is true. Is the plaintiff justly entitled to be put in any better position than he was in before the tort was committed? If the defendant puts the plaintiff in the same position, is he not square with the world, or at least with the plaintiff? Is he not, as against the plaintiff, entitled to keep anything else that he has obtained? Perhaps the defendant ought

${ }^{80}$ Huganir v. Cotter, ro2 Wis., 323; Western Ins. Co. v. Towle, 65 Wis., 247. City Nat'l Bank v. Nat'l Park Bank, 32 Hun., ro5, holding one joint tort feasor liable in assumpsit for the whole sum obtained by the fraud, even though the defendant never received a portion of that sum, directly or indirectly, is incorrect.

81 Moses v. MacFerlan, 2 Burrow, 1005; Lockwood v. Kelsea, 41 N. H., 185; Lindon v. Hooper, Cowper, 414; Fiquet v. Allison, I2 Mich., 328; Young v. Marshall, 8 Bing., 43. In Foster v. Stewart, 3 Maule \& S., I9I, it is said by Bayley, J.: "It has often been laid down that you may waive the tort and bring assumpsit; because in assumpsit the party cannot recover more than in an action of tort; in many instances he will recover less."

82 Cf. Fitzsimmons v. Brooklyn, ro2 N. Y., 536, and U. S. v. Addison, 6 Wall., 29 r.

${ }^{88}$ Hitchin 2. Campell, 2 W. Bl., 827. 
to be punished for his tort, but if so the fine ought to go to the state, and it ought to be measured by the character of the wrong, and not by the amount of the profit made out of it by the defendant. It is true that for some torts punitive damages are assessable, and the plaintiff as a prosecutor for the state gets them. But the desirability of assessing punitive damages has never been given as a reason for suing in assumpsit, and such damages are in fact foreign to the character of a contract action.

If express assumpsit had remained what it originally was, an action for damages for a deceit, certainly the recovery would never exceed the plaintiff's injury as found. But assumpsit came, by a process not yet traced in detail, ${ }^{84}$ to be an action for the breach of an obligation based on consent, and the measure of damages changed from the amount of damage suffered by the promisee, to the value of the thing promised, the amount he would have gained had the promise been performed. This may be proper and right in actions on real contracts based on consent, but it is entirely unnecessary and improper to apply the rule to obligations sounding in tort. In contract, the measure of damages is the amount of profit the parties might reasonably have foreseen would have been gained had the contract been performed. It is the extent of the disappointment-the amount the promisee would have been enriched by addition. In tort, the measure of damages is the amount actually suffered and proximately resulting from the wrong, whether that loss could have been foreseen or not. It is the amount taken away-the amount one has been deprived of by subtraction. It has been neatly said, the test in contract is foresight, and in tort it is hindsight. ${ }^{85}$ So in indebitatus assumpsit for a tort, the measure of damages should be the same as in a tort action, or at any rate no greater. The legal fiction should not be indulged to enlarge the right.

In conclusion, it would appear that there is grave doubt as to the propriety of the whole doctrine of waiver of tort and suit

84 Ames, in his History of Assumpsit, merely says: "By a natural transition, however, actions upon parol promises came to be regarded as actions ex contractu. Damages were soon assessed, not upon the theory of reimbursement for the loss of the thing given for the promise, but upon the principle of compensation for the failure to obtain the thing promised."

${ }^{85}$ Street: Foundations of Legal Liability, Vol. I, p. 89. 
in assumpsit, a doubt that has been expressed by many judges. ${ }^{86}$ Perhaps the best thing that can be said of it is that it was a step in the breaking down of the common law forms of action. The injured party certainly already had an adequate remedy at law. The actions of trespass, trover, detinue, and replevin were open to him. This was not true of other large classes of quasi-contracts, so that the extension of assumpsit to them was necessary. The courts profess to allow waiver of tort and suit in assumpsit only in cases where the plaintiff is helped without injuring the defendant. But in most cases it has in fact injured the defendant. The defendant has been held by this fiction in cases where the doctrine of non-survival of actions would have let him go scot free. Counterclaims have been allowed, where otherwise the defendant on the counterclaim would not have had to meet it. In a few cases the amount of the recovery may have been increased. By the use of this fiction, the defendant's right given him by the statute of limitations has been cut down. The plaintiff's pleading in all these cases is much less specific, and the defendant much more likely to be surprised by the case presented at the trial. It seems certain that in all of these cases the defendant has been injured, and it has really been for the sake of these injuries that the right to sue in assumpsit was allowed, thus creating a new quasi-contractual right. It is true that there are some compensating benefits for the tort feasor, but he might have some interest in deciding as to their weight himself. Difficulties in the construction of statutes have been increased, the doctrine of election of remedies has been greatly complicated, and an immense number of conflicting decisions due to misunderstanding has resulted.

However, the doctrine has been permanently engrafted on the common law, and it should now be applied along consistent lines with a correct understanding of the nature of the cause of action and the character of the remedy. In jurisdictions where the old forms of action have been totally abolished, there should be nothing whatever left of the whole doctrine excepting a few historical echoes. ${ }^{87}$ Arthur L. Corbin.

Yale University Lazu School.

${ }^{86}$ Holt, C. J., in Constable's Case, Comb., 446; Scroggs, C. J., in Howard v. Wood, T. Jones, 126, I28; Ellenborough, C. J., in Foster v. Stewart, 3 Maule \& S., I9I; Martin, B., in Neate v. Harding, 6 Exch., 349; York v. Toun, 5 Mod., 444, and see Lamine v. Dorrell, a Ld. Raym., 1216.

87 e. $g$. It should still have an influence in the construction of statutes. See Ingram v. U. S., $32 \mathrm{Ct}$. of Clms., r.47. 